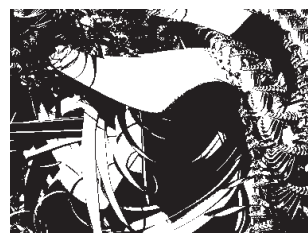

\title{
HRVATSKA U POSTINDUSTRIJSKO DOBA - PROMJENE U STRUKTURI RADNO AKTIVNOGA STANOVNIŠTVA PO SEKTORIMA DJELATNOSTI I SPOLU
}

Krešimir PERAČKOVIĆ

Institut društvenih znanosti Ivo Pilar, Zagreb

UDK: $331.101 .232(497.5)$

$314.17(497.5): 331$

$314.145(497.5): 331$

Pregledni rad

Primljeno: 8. 1. 2010.

U hrvatskom je društvu u proteklih pola stoljeća došlo do radikalne promjene u strukturi dielatnosti. Nakon Drugoga svjetskog rata započinje faza deagrarizacije i socijalističke industrijalizacije, koja doseže vrhunac potkraj 1960-ih i na početku 1970-ih godina. Već od 1970-ih započinje masovni ulazak žena na tržište rada i proces tercijarizacije, ali i deindustrijalizacije, koji u 90-im godinama postaju i dominantni procesi u promjenama strukture dielatnosti. Osim same analize promjena, cilj je ovoga rada istaknuti relevantnost i aktualnost nekih, danas već klasičnih, teorijskih koncepata u radovima ekonomskih teoretičara Fishera, Clarka i Rostowa, na čijim temeljima nastaje i suvremeni koncept postindustrijskoga društva u dielima sociologa Bella, Tourainea i Castellsa. Polazeći od temelinih teza navedenih autora kao teorijskog okvira, prikazana je analiza promjena u strukturi aktivne radne snage po sektorima dielatnosti i spolu na temelju rezultata svih popisa stanovništva od 1971. do 2001. Na kraju se razmatraju i mogući čimbenici koji utječu na te promiene, kao i neke posljedice do kojih taj proces dovodi.

Ključne riječi: postindustrijsko društvo, društvo usluga, deindustrijalizacija, tercijarizacija, struktura djelatnosti

$\triangle \quad$ Krešimir Peračković, Institut društvenih znanosti Ivo Pilar, Marulićev trg 19/1, p. p. 277, 10001 Zagreb, Hrvatska. E-mail: Kresimir.Perackovic@pilar.hr 
Iako je koncept postindustrijskoga društva ${ }^{1}$ danas prepoznatljiv kao sociološki pristup novijim teorijama o suvremenoj podjeli rada koja se očituje ponajprije u promjenama strukture djelatnosti ${ }^{2}$ i zanimanja najrazvijenijih zemalja, važno je istaknuti da su se tom temom, iako ne pod tim nazivom, najprije bavili ekonomski teoretičari još u prvoj polovici 20. stoljeća koji su pisali o stupnjevima ekonomskog rasta i tipologiji grana privrednih djelatnosti, a kasnije i demografi. Podjelu na primarni, sekundarni i tercijarni sektor privrede prvi je predložio A. G. B. Fisher u knjizi Sukob napretka i sigurnosti, što je kasnije podrobnije razradio $\mathrm{u}$ članku pod naslovom Production, Primary, Secondary and Tertiary, objavljenom u časopisu Economic Record (Fisher, 1939.) Njegovu teoriju produbljuje Colin Clark u djelu The Conditions of Economic Progress (1957.), koji tu podjelu analizira prema kriteriju podjele rada, pa primarni sektor naziva ekstraktionim, sekundarni proizvodnim, a tercijarni uslužnim. Stoga ekonomski razvoj Clark definira kao stopu prijelaza radne snage iz jednoga sektora u drugi sektor, a ta je stopa označavala funkciju različite produktivnosti između sektora. Tek kasnije je W. W. Rostow u djelu Stupnjevi ekonomskog rasta - nekomunistički manifest iz 1953. preformulirao tu teoriju i dao joj konačan oblik, podijelivši sva društva prema ekonomskoj dimenziji na pet stupnjeva ekonomskoga rasta: tradicionalna društva, društva u kojima se stvaraju uvjeti za "uzlet", društva u razdoblju "uzleta", društva koja idu "prema zrelosti" i društva u razdoblju visoke masovne potrošnje (Rostow, 1997., 4).

Ti autori u svojim radovima zaključuju kako gospodarski razvoj podrazumijeva smanjenje udjela primarnih djelatnosti i zanimanja (poljoprivrede, šumarstva, lova i ribolova te rudarstva) i njihova udjela $u$ formiranju nacionalnoga proizvoda. Već se tada uvidjelo da sekundarne djelatnosti (industrija i građevinarstvo) apsorbiraju radnu snagu koja napušta primarne djelatnosti te ju zapošljava s još većom proizvodnosti čime je bio omogućen privredni rast, što je zaključio i C. Clark. Analizirajući porast udjela usluga u svjetskom gospodarstvu, Jovančević u svojem članku ističe kako već nakon Drugoga svjetskog rata dinamički razvoj svjetskih privreda pokazuje da s gospodarskim razvojem dominantni sektor postaju uslužne djelatnosti - $\mathrm{i}$ u pogledu zaposlenosti i u doprinosu u BDP-u (Jovančević, 1997., 53), pa time tercijarni sektor preuzima funkciju apsorpcije radne snage od sekundarnoga.

U hrvatskom je društvu također u proteklih pola stoljeća došlo do radikalne promjene u strukturi djelatnosti. Nakon Drugoga svjetskog rata uvođenjem socijalističkoga poretka započinje faza deagrarizacije i industrijalizacije, koja doseže vrhunac 
DRUŠ. ISTRAŽ. ZAGREB GOD. $20(2011)$, BR. 1 (1 111$)$, STR. $89-110$

PERAČKOVIĆ, K.: HRVATSKA U... potkraj 1960-ih i na početku 1970-ih godina (Wertheimer-Baletić, 1978.). Međutim, već od sredine 1970-ih započinje intenzivno i proces tercijarizacije, ${ }^{3}$ već tada preobražavajući strukturu djelatnosti, koja počinje poprimati postindustrijska obilježja. $\mathrm{U}$ ovom radu analizirat će se promjene $\mathrm{u}$ strukturi djelatnosti u ukupnoj populaciji radno aktivnoga stanovništva, odnosno radne snage, kao i prema spolu, što je osobito važno zbog masovnijeg ulaska žena na tržište rada, što osjetno pridonosi promjenama te strukture. Analiza se temelji na svim popisima stanovništva od 1971. do 2001., pa će se razmotriti čimbenici koji utječu na te promjene i posljedice do kojih taj proces dovodi. Budući da su u domaćoj literaturi rijetki radovi koji detaljnije konceptualiziraju pojam postindustrijsko, treba najprije ukratko prikazati i neka temeljna obilježja postindustrijskoga društva prema, danas već klasičnim, teorijama D. Bella i A. Tourainea, kao i suvremeni sociološki pristup M. Castellsa.

\section{TEORIJSKI OKVIR:}

\section{TEMELJNA OBILJEŽJA POSTINDUSTRIJSKOGA DRUŠTVA}

Američki sociolog Daniel Bell u svojoj knjizi Dolazak postindustrijskoga društva (The Coming of Postindustrial Society) ${ }^{4}$ iz 1976. prvi među sociolozima analizira zamjetne promjene $u$ društvenoj podjeli rada započete sredinom 20. stoljeća u SAD-u i u tadašnjem Sovjetskom Savezu te upozorava na radikalno smanjenje zaposlenih u industrijskom sektoru. ${ }^{5}$ Osim njega, kao jednog od prvih teoretičara postindustrijskoga društva treba istaknuti i francuskoga sociologa Alaina Tourainea, koji uoči i nakon studentskih pokreta 1968. u tradiciji konfliktnih teorija istražuje najvažnije konflikte u novonastajućem postindustrijskom društvu i analizira najvažnije društvene skupine i nove strukture čiji su interesi suprotstavljeni. Bell u knjizi iznosi vrlo temeljitu komparativnu analizu o tri tipa društva s obzirom na način proizvodnje i tehnologiju, ekonomski sektor i resurse, zanimanja i način rada, metodologiju, vremensku perspektivu, prevladavajuće djelovanje te temeljni princip. Najvažniji uvidi prikazani su u Tablici 1 , koju donosimo u cijelosti, jer knjiga kod nas nije prevedena, a ni ova shema nije prikazana u domaćoj periodici.

Ukratko, Bell zaključuje kako su u drugoj polovici 20. stoljeća razvijene zapadne zemlje već postale postindustrijska društva, međutim ta promjena započinje i u bivšim socijalističkim zemljama, bez obzira na drugačiji politički i ideološki sustav, ponajprije primjenom automatizacije u proizvodnji. Postindustrijsko društvo Bell definira uz pomoć ovih pet najvažnijih obilježja. Prvo je obilježje očita promjena u ekonomskom sektoru od proizvodne ekonomije u uslužnu, jer se razvija više vrsta usluga, a osobito je važan porast u istraživanju i vla- 
DRUŠ. ISTRAŽ. ZAGREB GOD. 20 (2011) BR. 1 (111)

STR. 89-110

PERAČKOVIĆ, K. HRVATSKA U...

(1) TABLICA 1

Od industriijskoga prema postindustriiskom društvu: Bellova generalna shema društvene promjene dinim uslugama, što dovodi do nove intelektualne elite. Drugo je obilježje promjena u strukturi zanimanja i samoj vrsti rada, gdje sada prevladavaju profesionalna i uslužna zanimanja. Autor naglašava kako općenito u velikoj mjeri zanimanje postaje najvažnija determinanta klasne strukture i stratifikacije $\mathrm{u}$ društvu te kaže ako je PKV radnik dominirao $\mathrm{u}$ industrijskoj ekonomiji, uslužna je ekonomija povećala udio zanimanja u uredima, obrazovanju i vladi, pa je tako već 1956. broj bijelih ovratnika premašio broj plavih ovratnika. Treće je obilježje temeljni princip postindustrijskoga društva, a to je kodifikacija teorijskoga znanja, pohranjenog u sažecima i simbolima kao izvorima inovacija, ali i moguće političke (re)formulacije društva. Četvrto je obilježje orijentacija na budućnost uz kontrolu tehnologije i tehnoloških dostignuća. Peto je obilježje proces odlučivanja te stvaranje nove intelektualne tehnologije.

\begin{tabular}{|c|c|c|c|}
\hline & $\begin{array}{l}\text { Predindustrijsko } \\
\text { društvo }\end{array}$ & $\begin{array}{l}\text { Industrijsko } \\
\text { društvo }\end{array}$ & $\begin{array}{l}\text { Postindustrijsko } \\
\text { društvo }\end{array}$ \\
\hline Način proizvodnje & ekstraktivna privreda & industrijska proizvodnja & procesiranje informacija \\
\hline Ekonomski sektor & $\begin{array}{l}\text { primarni } \\
\text { poljoprivreda } \\
\text { rudarstvo } \\
\text { ribarstvo } \\
\text { šumarstvo } \\
\text { nafta i plin }\end{array}$ & $\begin{array}{l}\text { sekundarni } \\
\text { proizvodnja dobara } \\
\text { - trajnih } \\
\text { - potrošnih } \\
\text { teška industrija }\end{array}$ & $\begin{array}{lll}\text { uslužni } & & \\
\text { tercijarni: } & \text { kvartarni: } & \text { kvintarni: } \\
\text { transport } & \text { trgovina, } & \text { zdravstvo, } \\
\text { i osobne } & \text { financije, } & \text { obrazovanje, } \\
\text { usluge } & \text { osiguranje, } & \text { istraživanja, } \\
& \text { nekretnine } & \text { državna u- } \\
& & \text { prava, rekre- } \\
& & \text { acija i zabava }\end{array}$ \\
\hline Resursi & $\begin{array}{l}\text { prirodna snaga: } \\
\text { vjetar, voda, životinjska } \\
\text { snaga, ljudska snaga }\end{array}$ & $\begin{array}{l}\text { proizvedena energija: } \\
\text { nafta, plin, nuklearna } \\
\text { energija }\end{array}$ & $\begin{array}{l}\text { informacije i znanje: } \\
\text { programiranje i algoritmi, računala } \\
\text { i prijenos podataka }\end{array}$ \\
\hline Strateški resurs & sirovine & financijski kapital & ljudski kapital \\
\hline Tehnologija & ljudski rad & strojevi & intelektualna tehnologija \\
\hline Zanimanja & $\begin{array}{l}\text { obrtnici, manufakturni } \\
\text { i umjetnički rad, } \\
\text { poljoprivrednici }\end{array}$ & inženjeri, PKV radnici & $\begin{array}{l}\text { znanstvenici, tehničari i profesionalna } \\
\text { zanimanja }\end{array}$ \\
\hline Način rada & fizički rad & podjela rada & umreženje \\
\hline Metodologija & $\begin{array}{l}\text { zdravi razum, pokušaj- } \\
\text {-pogreška, iskustvo }\end{array}$ & empirija, eksperiment & $\begin{array}{l}\text { modeli, simulacije, teorija odlučivanja, } \\
\text { sistemska analiza }\end{array}$ \\
\hline $\begin{array}{l}\text { Vremenska } \\
\text { perspektiva }\end{array}$ & orijentacija na prošlost & $\begin{array}{l}\text { ad-hoc prilagodba, } \\
\text { eksperimentiranje }\end{array}$ & $\begin{array}{l}\text { orijentacija na budućnost: } \\
\text { planiranje i predviđanje }\end{array}$ \\
\hline $\begin{array}{l}\text { Prevladavajuće } \\
\text { djelovanje }\end{array}$ & odnos prema prirodi & $\begin{array}{l}\text { odnos prema proizve- } \\
\text { denoj "prirodi" }\end{array}$ & odnos između osoba \\
\hline Temeljni princip & tradicionalizam & proizvodnja & kodifikacija teoretskog znanja \\
\hline
\end{tabular}

Izvor: Bell, D. (1999.), The Coming of Postindustrial Society, Foreword 1999, New York, Basic Books, str. 85. 
DRUŠ. ISTRAŽ. ZAGREB GOD. 20 (2011), BR. $1(111)$ STR. $89-110$

PERAČKOVIĆ, K. HRVATSKA U...
Bell razvija svoj koncept postindustrijskoga društva analizirajući promjene u privrednoj, odnosno - kako je on naziva - tehnoekonomskoj dimenziji društva, dok je Touraineov kritički pristup usredotočen na promjene u političkoj dimenziji društva, pa su stoga ta dva pristupa više komplementarna nego suprotstavljena. Tourainea u knjizi Postindustrijsko društvo (La société postindustrielle) iz 1969. zanima politička sfera društva shvaćena kao odnos moći te želi istražiti tko su akteri suprotstavljenih interesa u postindustrijskim društvima, kakva je priroda društvenih sukoba i moći te u kojoj se dimenziji društva sukob odvija. Osobito mu je zanimljivo istražiti što to vladajuće snage suzbijaju i što zbog toga suzbijanja uzrokuje društvene pokrete. On tvrdi kako se ta postindustrijska društva mogu nazvati tehnokratskima ako im se želi dati "ime moći" koja njima vlada, a ako ih se definira prema prirodi načina proizvodnje i privrednog uređenja, mogu se prozvati programiranima. Izraz programirano društvo najdirektnije pokazuje prirodu rada i privredne djelatnosti, a ekonomske odluke i ekonomske borbe u njemu više nemaju autonomiju i središnje mjesto kao u industrijskom društvu, koje je definirano naporima za akumulacijom i stjecanjem profita iz neposrednoga proizvodnog rada. Ekonomski mehanizmi više nisu u središtu društvene organizacije i ekonomski je rast sada više rezultat zbroja društvenih faktora nego same akumulacije kapitala, pa sve više izravno ovisi o spoznaji i sposobnosti društva da stvara nove spoznaje. Stoga, poput Bella, samo drugim terminom, Touraine zaključuje kako je znanost sada ključna proizvodna snaga društva, a glavni društveni sukob više nije između rada i kapitala nego između aparata ekonomskog i političkog odlučivanja i onih koji su se podredili ovisnoj participaciji, a to je za Tourainea glavno obilježje promjene u postindustrijskom društvu.

U knjizi Uspon umreženoga društva jedna od Castellsovih glavnih teza jest kako je najutjecajniji povijesni čimbenik koji ubrzava, kanalizira i oblikuje paradigmu informacijske tehnologije i koji uvjetuje s njom povezane društvene oblike još uvijek proces kapitalističke restrukturacije započet 1980-ih, pa stoga taj novi tehnoekonomski sustav postindustrijskoga društva Castells naziva informacijskim kapitalizmom (Castells, 2000., 53). Polazeći od glavnih postavki Bella i Tourainea, Castells operacionalizira teoriju postindustrijalizma kroz tri glavne hipoteze od kojih polazi u svom istraživanju temeljenom na statističkim podacima zemalja skupine G7: 1) izvor rasta i produktivnosti leži u stvaranju znanja koje se proširuje na gospodarstvo obradbom informacija, 2) gospodarska djelatnost premješta se s dobra na usluge, a prevladavajući udio zaposlenosti leži u uslužnom sektoru, 3) povećava se važnost zanimanja koja u svojoj djelatnosti sadrže veliku količinu infor- 
DRUŠ. ISTRAŽ. ZAGREB GOD. 20 (2011), BR. $1(111)$

STR. 89-110

PERAČKOVIĆ, K. HRVATSKA U... macija i znanja, pa stoga menadžerska, stručna i tehnička zanimanja rastu brže od bilo kojih drugih zanimanja te čine srž nove socioprofesionalne strukture. Uspoređujući rezultate svake pojedine zemlje, autor prije svega prihvaća navedene hipoteze i zaključuje da sve navedene zemlje imaju neke zajedničke osobine koje su uistinu obilježja postindustrijskih i informacijskih društava, a to su: istiskivanje zaposlenosti u poljoprivredi, stalno opadanje tradicionalne zaposlenosti $u$ industriji, uspon proizvodnih i društvenih usluga, s naglaskom na poslovnim uslugama u prvoj kategoriji te zdravstvenih usluga u drugoj kategoriji, povećana raznolikost uslužnih djelatnosti kao izvor novih radnih mjesta, brz uspon menadžerskih, stručnih i tehničkih poslova, stvaranje proletarijata "bijelih ovratnika" koji čine radnici u trgovini i uredima, razmjerna stabilnost značajnoga dijela zaposlenosti u trgovini na malo, istodobno povećanje viših i nižih razina strukture zanimanja i, na kraju, razmjerno unapređivanje strukture zanimanja tijekom vremena: povećava se udio zanimanja koja zahtijevaju više vještine i više obrazovanje, a taj je porast razmjerno veći od porasta kategorija nižega stupnja (Castells, 2000., 258). Polazeći od ovih spoznaja, postavilo se pitanje kakva je situacija u Hrvatskoj i je li i Hrvatska postala prema nekim pokazateljima postindustrijsko društvo. Imajući na umu kompleksnost i složenost cjelokupnoga modela postindustrijskoga društva i pripadajućih mu indikatora, čija bi analiza i istraživanje zahtijevali veći interdisciplinarni istraživački projekt, u ovom članku zbog ograničenosti prostora nije moguće analizirati više obilježja, nego će žarište biti na temeljnom i najvažnijem indikatoru: promjenama u strukturi djelatnosti.

\section{EMPIRIJSKA ANALIZA: PROMJENE U STRUKTURI DJELATNOSTI6 U HRVATSKOJ OD 1971. DO 2001.}

\section{Dosadašnje spoznaje}

Analizama promjena $u$ strukturi djelatnosti bavili su se najviše Wertheimer-Baletić (1978., 1991., 1999.) i Akrap (1996.) do 1990-ih godina. U tim je radovima istaknuto kako je proces industrijalizacije dovršen još u socijalizmu te da je uslužni sektor već tada rastao i postao vodeći u trosektorskoj podjeli. Wertheimer-Baletić zaključuje kako je aktivno stanovništvo prema pojedinim djelatnostima i sektorima djelatnosti "opći izraz privredne razvijenosti određenog područja, odnosno izraz stupnja dostignutog gospodarskog razvoja" (Wertheimer-Baletić (1991., 41). Međutim, istodobno to je i obilježje diferenciranosti $\mathrm{u}$ društvenoj podjeli rada, $\mathrm{u}$ kretanju proizvodnosti rada, ali i u tehničko-tehnološkom razvoju pojedinih sektora 
DRUŠ. ISTRAŽ. ZAGREB GOD. 20 (2011), BR. 1 (1 111$)$, STR. $89-110$

PERAČKOVIĆ, K. HRVATSKA U... djela stanovništva na poljoprivredno i nepoljoprivredno u demografskim analizama predstavlja agregatni izraz ekonomske strukture ukupnoga i aktivnoga stanovništva, a sam udio poljoprivrede u ukupnoj društvenoj proizvodnji i udio poljoprivrednoga stanovništva uvijek je važan pokazatelj ekonomskoga i društvenoga razvoja. Detaljniji izraz ekonomske strukture stanovništva jest podjela na privredne sektore djelatnosti (primarni, sekundarni i tercijarni), a još je detaljniji izraz struktura stanovništva po pojedinim djelatnostima, granama, strukama i zanimanjima.

Ovdje je važno istaknuti da pojam radno aktionoga stanovništva, odnosno radne snage, nije isto što i pojam zaposlenosti radne snage, jer prvi obuhvaća i nezaposlene. Pojam radno aktivnoga stanovništva podrazumijeva "obavljanje nekog zanimanja radi stjecanja sredstava za život" (Wertheimer-Baletić, 1999., 410), a obuhvaća: 1) sve zaposlene osobe (osobe $\mathrm{u}$ radnom odnosu) koje rade puno radno vrijeme, pola radnoga dana i više te one koje rade manje od polovice prosječnoga radnog dana; sve osobe koje aktivno obavljaju određeno zanimanje, ali nisu u radnom odnosu (aktivni u poljoprivredi, obrtu, osobe koje rade za "vlastiti račun", pomažući članovi obitelji); 2) nezaposlene osobe $u$ određenom razdoblju (koje traže zaposlenje dulje od mjesec dana): nezaposlene koji su prije bili zaposleni i osobe koje prvi put traže posao; 3 ) osobe koje su prekinule rad zbog ispunjenja vojne obveze ili izdržavanja kazne. Stoga analiza promjena u strukturi zaposlenosti po sektorima djelatnosti više upućuje na trenutačno stanje tržišta rada, dok analiza promjene ukupnoga radno aktivnog stanovništva upućuje na dugoročnije historijske, socioekonomske i sociodemografske procese. Od domaćih autora, o transformaciji strukture zaposlenosti u postindustrijskom društvu pisao je najprije Baletić (1998.), a temeljitiju analizu promjena u strukturi zaposlenosti donosi Matković prema anketi o radnoj snazi, koji također uočava smanjenje zaposlenosti u ekstraktivnim i transformativnim djelatnostima, odnosno u primarnom i sekundarnom sektoru te rast uslužnih djelatnosti (Matković, 2003.).

Jedna je od novijih i analiza promjena u strukturi zanimanja u Hrvatskoj prema popisima stanovništva od 1971. do 2001. u kontingentu radno aktivnih, gdje je također istaknuto kako istraživanja o strukturi zanimanja koja polaze od ekonomskih i demografskih teorija upućuju na povezanost sa strukturom djelatnosti i grana djelatnosti, no te strukture nisu identične ni potpuno korelirane, jer je struktura zanimanja diferenciranija nego struktura djelatnosti. Ta je analiza pokazala kontinuiran i stepenast rast uslužnih zanimanja, ali i smanjenje industrijskih zanimanja još prije 1990-ih godina, pa je u 
zaključku istaknuto da u strukturi zanimanja prevladava proces tercijarizacije, čime struktura zanimanja u Hrvatskoj poprima obilježje postindustrijske podjele rada u kojoj prevladavaju uslužna zanimanja (Peračković, 2007.).

\section{Ciljevi i hipoteza}

Polazeći od glavne teze iz teorije postindustrijskoga društva, dosadašnjih demografskih analiza te navedenih radova, temeljni cilj ovoga rada jest istražiti je li i Hrvatska poprimila glavno obilježje postindustrijskoga društva prema Bellovu prvom indikatoru, odnosno ima li postindustrijsku strukturu djelatnosti, te koji su mogući čimbenici promjena u strukturi djelatnosti. Glavna je hipoteza da postoji kontinuirani proces deagrarizacije, deindustrijalizacije i tercijarizacije te da Hrvatska poprima postindustrijsku strukturu djelatnosti. Razdoblje 1990-ih kao tranzicijsko razdoblje bilo je osobito važno za taj proces i zbog utjecaja tehnološke modernizacije i demografskih promjena i zbog procesa privatizacije, zbog kojeg su industrijske djelatnosti gotovo "prisilno" i masovno nestajale.

\section{Izvori podataka i metoda}

Glavni izvor podataka jesu popisi stanovništva, pa će se i u ovoj analizi rabiti metoda demografske statistike uz komparativnu analizu sukcesivnih popisa praćenih obilježja u definiranom razdoblju, dakle na statističkim podacima čitave populacije.7 Izvori podataka jesu: popisne knjige i tablogrami popisa stanovništva iz 1971. i 1991., statistički godišnjak za 1981., a za 2001. tablogrami dostupni i na internetskoj stranici Državnoga zavoda za statistiku Republike Hrvatske. Također je važno naglasiti da se u interpretaciji dobivenih rezultata rabio pristup koji je primijenila A. Wertheimer-Baletić u svojim analizama iz ranijih međupopisnih razdoblja, a njezini najvažniji rezultati jesu polazišna osnova i u interpretaciji ove analize jer objašnjavaju početak procesa postindustrijske preobrazbe.

Prema metodologiji tih ranijih istraživanja, izračunani su relativni brojevi, odnosno postotci, prema tablicama s apsolutnim brojevima iz navedenih izvora, koji prikazuju strukturu djelatnosti. Za svaku popisnu godinu izrađen je grafički prikaz strukture djelatnosti prema granama djelatnosti za ukupno radno aktivno stanovništvo i strukture prema spolu zasebno, što je osobito važno zbog sve većeg udjela žena u kontingentu radne snage. Na kraju je i usporedni prikaz svih popisnih godina zajedno prema sektorima djelatnosti za ukupno radno aktivno stanovništvo te prema spolu.

Prije samoga prikaza strukture djelatnosti važno je napomenuti da se kategorizacija i klasifikacija djelatnosti donekle 
DRUŠ. ISTRAŽ. ZAGREB GOD. 20 (2011), BR. 1 (1 111$)$, STR. $89-110$

PERAČKOVIĆ, K.: HRVATSKA U... mijenjala, što je i dodatni razlog da se radi mogućnosti usporedbe izvrši segmentiranje prema klasičnoj podjeli na primarni, sekundarni i tercijarni sektor. Obrtništvo / zanatstvo je u 1971. i 1981. bilo u sekundarnom sektoru, a 1991. i 2001. dio onih obrtnika koji se bave poljoprivredom uvršten je u primarni, mali poduzetnici proizvođači u sekundarni, a tehnički serviseri i osobne usluge u tercijarni. U popisu iz 1981. trgovina je izdvojena, a ugostiteljstvu je pridružen turizam, koji se kao djelatnost 1971. uopće ne spominje. Saobraćaj je preimenovan u promet i veze, a kao djelatnost izdvojena je i vodoprivreda, koja se pojavljuje u popisu tek 1981. Budući da nije jasno naznačeno u izvorima, pretpostavlja se da je ranije vodoprivreda bila pribrojena poljoprivredi i šumarstvu. Zanatstvo se 1981. naziva obrtništvom, promet se proširuje na promet i veze, izdvajaju se financije i druge usluge, kulturi se pribraja obrazovanje, izdvaja se i zdravstveno-socijalna zaštita.

Godine 1991. pod istu su kategoriju djelatnosti navedeni obrtništvo i osobne usluge, a stambeno-komunalne djelatnosti sada uključuju i uređenje naselja i prostora. Financije i druge usluge sada se zovu financije, tehničke i poslovne usluge, obrazovanju i kulturi pridružuju se znanost i informacije, a zdravstveno-socijalna zaštita preimenovana je u zdravstvenu zaštitu i socijalnu skrb. Socijalističku nomenklaturu društveno-političke organizacije i SIZ-ova sada zamjenjuje kategorija tijela državne vlasti, tijela lokalne samouprave, fondovi, udruženja i organizacije. U popisu iz 2001. u odnosu na 1991. također je došlo do zamjetnih promjena u djelatnostima: rudarstvo je zasebna kategorija, industrija je sada prerađivačka industrija, združeni su poljoprivreda, lov i šumarstvo, dok je ribarstvo zasebno, vodoprivreda je proširena na opskrbu električnom energijom, plinom i vodom, prijevozu i vezama pridodano je skladištenje, trgovina se proširuje na trgovinu na veliko i malo, kojima su pribrojene tehničke usluge, tj. popravci motornih vozila te predmeta za osobnu upotrebu u kućanstvu, a obrtništvo se uopće ne navodi kao zasebna djelatnost. Umjesto ugostiteljstva i turizma, sada se te djelatnosti registriraju kao hoteli i restorani, a umjesto kategorije stambeno-komunalne djelatnosti i uređenje naselja i prostora iz 1991., sada se javlja kao djelatnost poslovanje nekretninama, iznajmljivanje i poslovne usluge, dok su financijske usluge prikazane kao zasebna djelatnost, tj. kao financijsko posredovanje. Obrazovanje je izdvojeno, a znanost, kultura i informacije objedinjuju se u kategoriju ostale društvene, socijalne osobne uslužne djelatnosti. Tijela državne vlasti, tijela lokalne samouprave, fondovi, udruženja i organizacije sada su u kategoriji koja obuhvaća javnu upravu i obranu te obvezno socijalno osiguranje. Nove djelatnosti su izvanteritorijalne organizacije i tijela te privatna kućanstva sa zaposlenim osobljem. 


\section{Rezultati}

(1) TABLICA 2 prije je u Tablici 2 prikazana klasifikacija djelatnosti prema svaSektori prema dielatnostima od kom od promatranih popisa. Slike 1, 2, 3 i 4 prikazuju strukturu prema djelatnosti i spolu pojedinačno za svaku popisnu 1971. do 2001. godinu u postotcima, a slika 5 prikazuje usporedbu po sektorima djelatnosti (primarni, sekundarni i tercijarni) i spolu.

\begin{tabular}{|c|c|c|c|c|}
\hline Sektori & $\begin{array}{l}\text { Djelatnosti } \\
1971 .\end{array}$ & $\begin{array}{l}\text { Djelatnosti } \\
1981 .\end{array}$ & $\begin{array}{l}\text { Djelatnosti } \\
1991 .\end{array}$ & $\begin{array}{l}\text { Djelatnosti } \\
2001 .\end{array}$ \\
\hline \multirow[t]{3}{*}{ Primarni } & $\begin{array}{l}\text { poljoprivreda } \\
\text { i ribarstvo }\end{array}$ & $\begin{array}{l}\text { poljoprivreda } \\
\text { i ribarstvo }\end{array}$ & $\begin{array}{l}\text { poljoprivreda } \\
\text { i ribarstvo }\end{array}$ & $\begin{array}{l}\text { poljoprivreda, } \\
\text { lov i šumarstvo }\end{array}$ \\
\hline & šumarstvo & šumarstvo & šumarstvo & ribarstvo \\
\hline & & vodoprivreda & vodoprivreda & $\begin{array}{l}\text { opskrba električnom ener- } \\
\text { gijom, plinom i vodom }\end{array}$ \\
\hline \multirow[t]{3}{*}{ Sekundarni } & $\begin{array}{l}\text { industrija } \\
\text { i rudarstvo }\end{array}$ & $\begin{array}{l}\text { industrija } \\
\text { i rudarstvo }\end{array}$ & $\begin{array}{l}\text { industrija } \\
\text { i rudarstvo }\end{array}$ & $\begin{array}{l}\text { prerađivačka } \\
\text { industrija }\end{array}$ \\
\hline & građevinarstvo & građevinarstvo & građevinarstvo & rudarstvo \\
\hline & zanatstvo & obrtništvo & & građevinarstvo \\
\hline \multirow[t]{11}{*}{ Tercijarni } & saobraćaj & promet i veze & promet i veze & prijevoz, skladištenje i veze \\
\hline & $\begin{array}{l}\text { trgovina } \\
\text { i ugostiteljstvo }\end{array}$ & trgovina & trgovina & $\begin{array}{l}\text { trgovina na veliko i ma- } \\
\text { lo; popravak motornih vozila } \\
\text { te predmeta za osobnu upotre- } \\
\text { bu u kućanstvu }\end{array}$ \\
\hline & & $\begin{array}{l}\text { ugostiteljstvo } \\
\text { i turizam }\end{array}$ & $\begin{array}{l}\text { ugostiteljstvo } \\
\text { i turizam }\end{array}$ & hoteli i restorani \\
\hline & $\begin{array}{l}\text { stambena i komu- } \\
\text { nalna djelatnost }\end{array}$ & $\begin{array}{l}\text { stambeno-komu- } \\
\text { nalna djelatnost }\end{array}$ & $\begin{array}{l}\text { stambeno-komunal- } \\
\text { ne djelatnosti i ure- } \\
\text { đenje naselja i prostora }\end{array}$ & $\begin{array}{l}\text { poslovanje nekretninama, } \\
\text { iznajmljivanje, poslovne usluge }\end{array}$ \\
\hline & & $\begin{array}{l}\text { financije i } \\
\text { druge usluge }\end{array}$ & $\begin{array}{l}\text { financije, tehničke } \\
\text { i poslovne usluge }\end{array}$ & financijsko posredovanje \\
\hline & $\begin{array}{l}\text { kultura i soci- } \\
\text { jalna djelatnost }\end{array}$ & $\begin{array}{l}\text { obrazovanje } \\
\text { i kultura }\end{array}$ & $\begin{array}{l}\text { obrazovanje, znanost, } \\
\text { kultura i informacije }\end{array}$ & obrazovanje \\
\hline & & $\begin{array}{l}\text { zdravstveno-soci- } \\
\text { jalna zaštita }\end{array}$ & $\begin{array}{l}\text { zdravstvena zaštita } \\
\text { i socijalna skrb }\end{array}$ & $\begin{array}{l}\text { zdravstvena zaštita } \\
\text { i socijalna skrb }\end{array}$ \\
\hline & & $\begin{array}{l}\text { obrtništvo i } \\
\text { osobne usluge }\end{array}$ & & $\begin{array}{l}\text { ostale društvene, socijalne i } \\
\text { osobne uslužne djelatnosti }\end{array}$ \\
\hline & $\begin{array}{l}\text { djelatnost dru- } \\
\text { štvenih i držav- } \\
\text { nih službi }\end{array}$ & $\begin{array}{l}\text { društveno-politič- } \\
\text { ke org. i SIZ-ovi }\end{array}$ & $\begin{array}{l}\text { tijela državne vlasti, } \\
\text { tijela lokalne samo- } \\
\text { uprave, fondovi, udru- } \\
\text { ženja i organizacije }\end{array}$ & $\begin{array}{l}\text { javna uprava i obrana; obvezno } \\
\text { socijalno osiguranje }\end{array}$ \\
\hline & & & & $\begin{array}{l}\text { privatna kućanstva sa zaposle- } \\
\text { nim osobljem }\end{array}$ \\
\hline & ostale djelatnosti & & & $\begin{array}{l}\text { izvanteritorijalne organizacije } \\
\text { i tijela }\end{array}$ \\
\hline
\end{tabular}




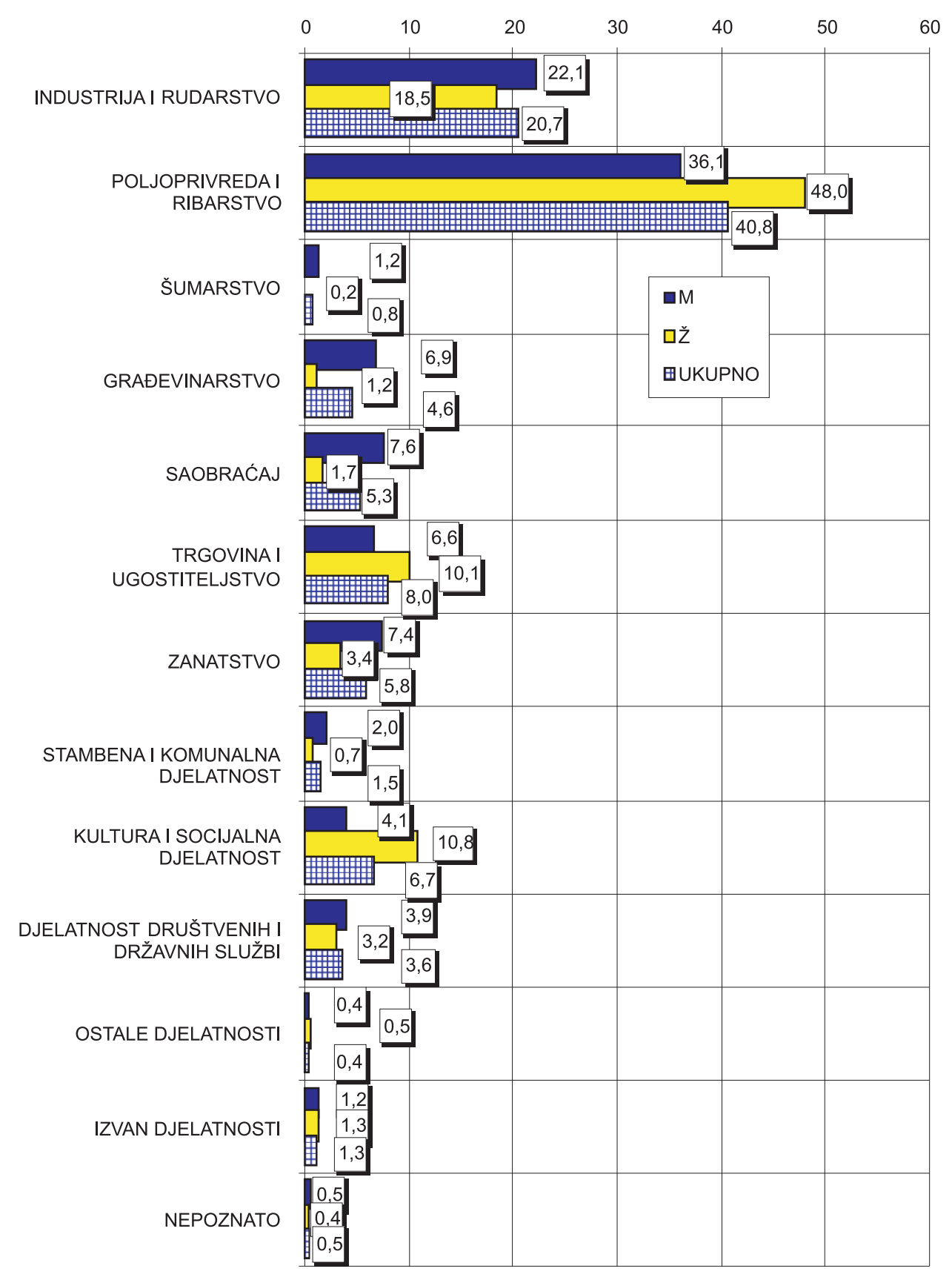

(1) SLIKA 1

Struktura radno

aktivnoga stanovništva

po sektorima 


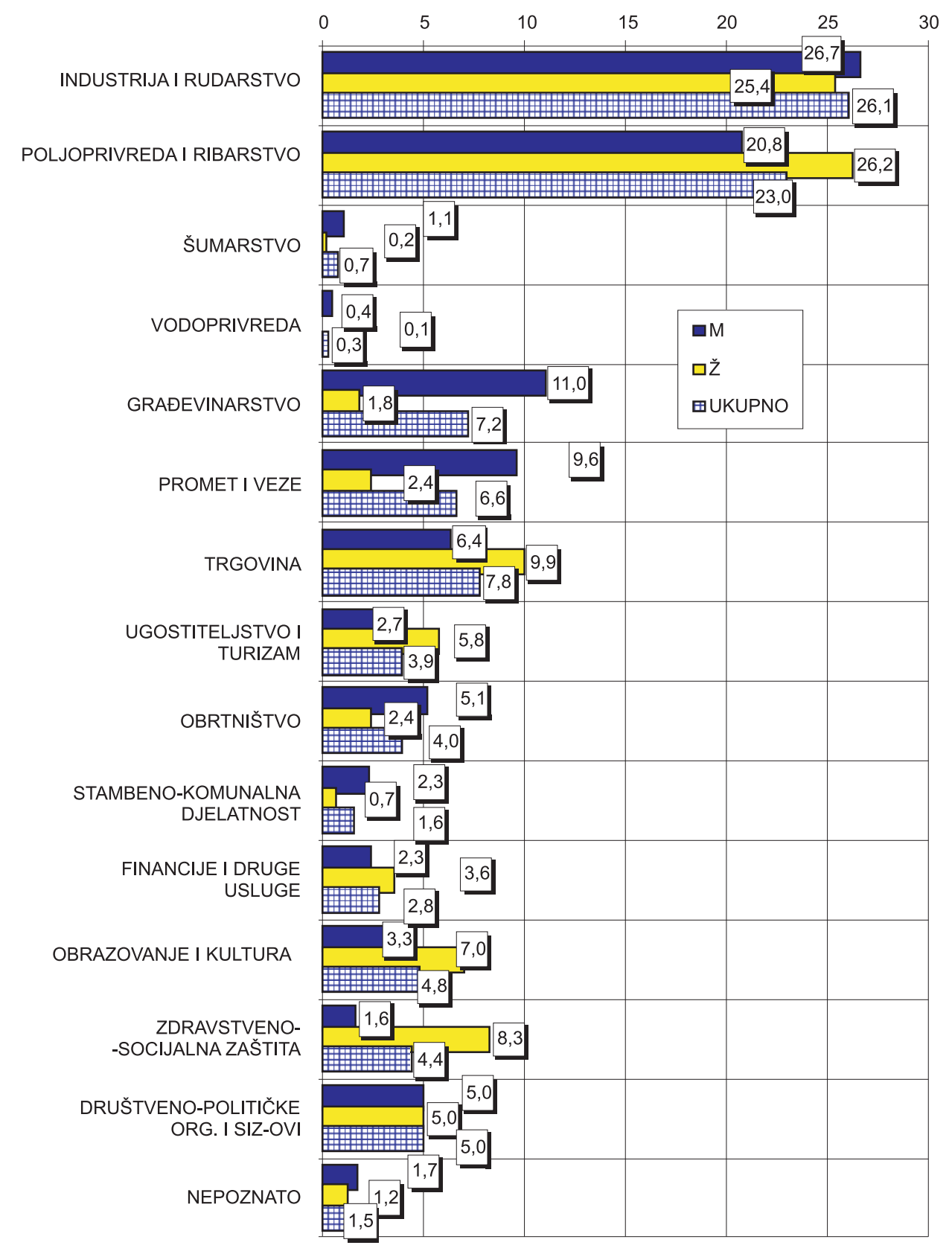

(1) SLIKA 2

Struktura radno

aktivnoga stanovništva

po sektorima 


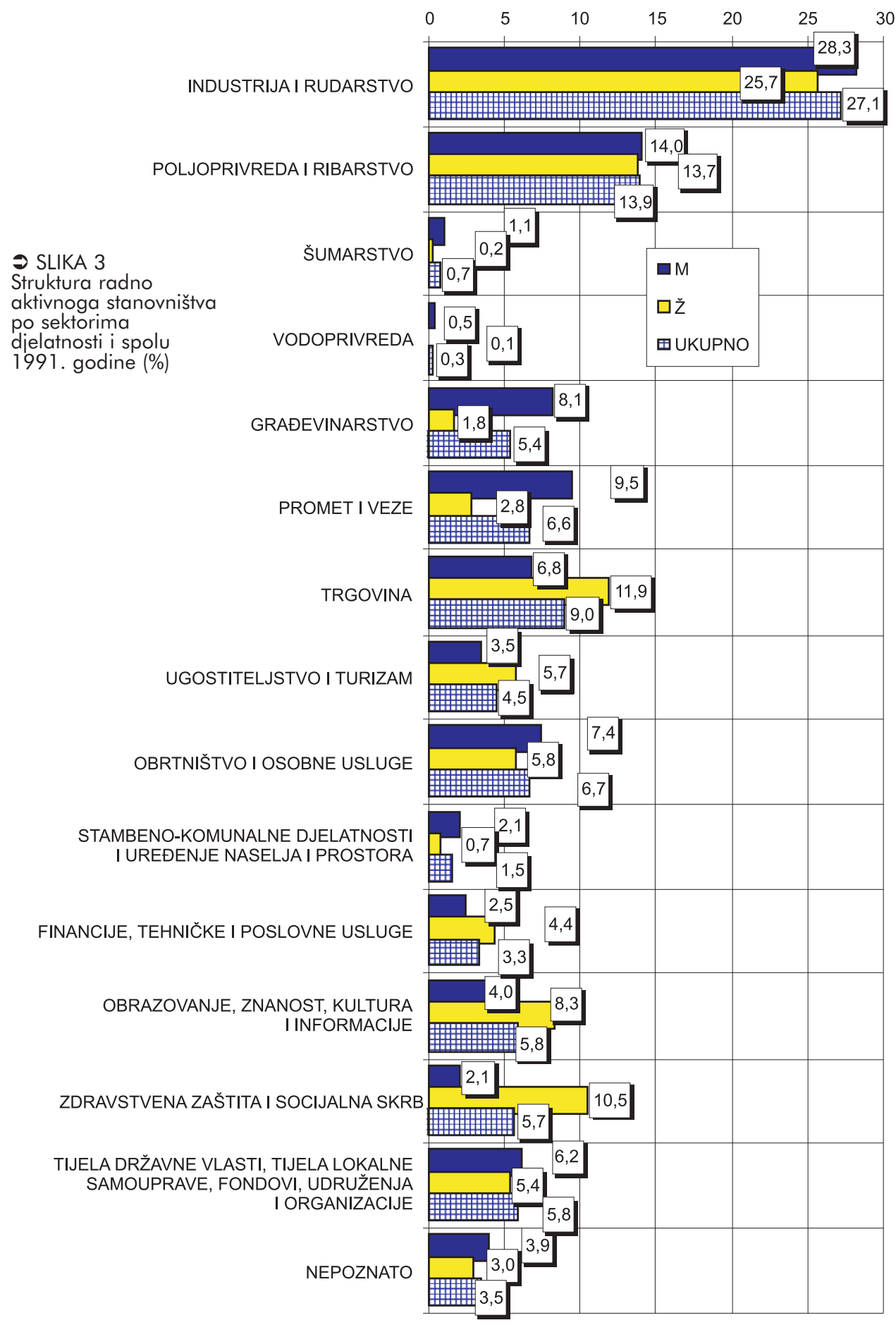


$\rightarrow$ SLIKA 4

Struktura radno

aktivnoga stanovništva

po sektorima

dielatnosti i spolu

2001. godine $(\%)$

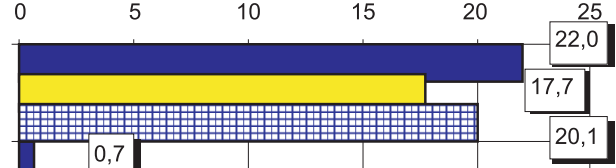

PRERAĐIVAČKA INDUSTRIJA

RUDARSTVO

POLJOPRIVREDA, LOV I ŠUMARSTVO

RIBARSTVO

OPSKRBA ELEKTRIČNOM ENERGIJOM, PLINOM I VODOM

GRAĐEVINARSTVO

PRIJEVOZ, SKLADIŠTENJE I VEZE

TRGOVINA NA VELIKO I MALO; POPRAVAK MOTORNIH VOZILA TE PREDMETA ZA OSOBNU UPOTREBU U KUĆANSTVU

HOTELI I RESTORANI

POSLOVANJE NEKRETNINAMA, IZNAJMLJIVANJE,

FINANCIJSKO POSREDOVANJE

OBRAZOVANJE

ZDRAVSTVENA ZAŠTITA I SOCIJALNA SKRB

OSTALE DRUŠTVENE, SOCIJALNE I OSOBNE USLUŽNE DJELATNOSTI

PRIVATNA KUĆANSTVA SA ZAPOSLENIM OSOBLJEM

$$
\begin{array}{r}
\text { JAVNA UPRAVA I OBRANA; } \\
\text { OBVEZNO SOCIJALNO OSIGURANJE } \\
\text { IZVANTERITORIJALNE ORGANIZACIJE I TIJELA } \\
\text { NEPOZNATA DJELATNOST }
\end{array}
$$
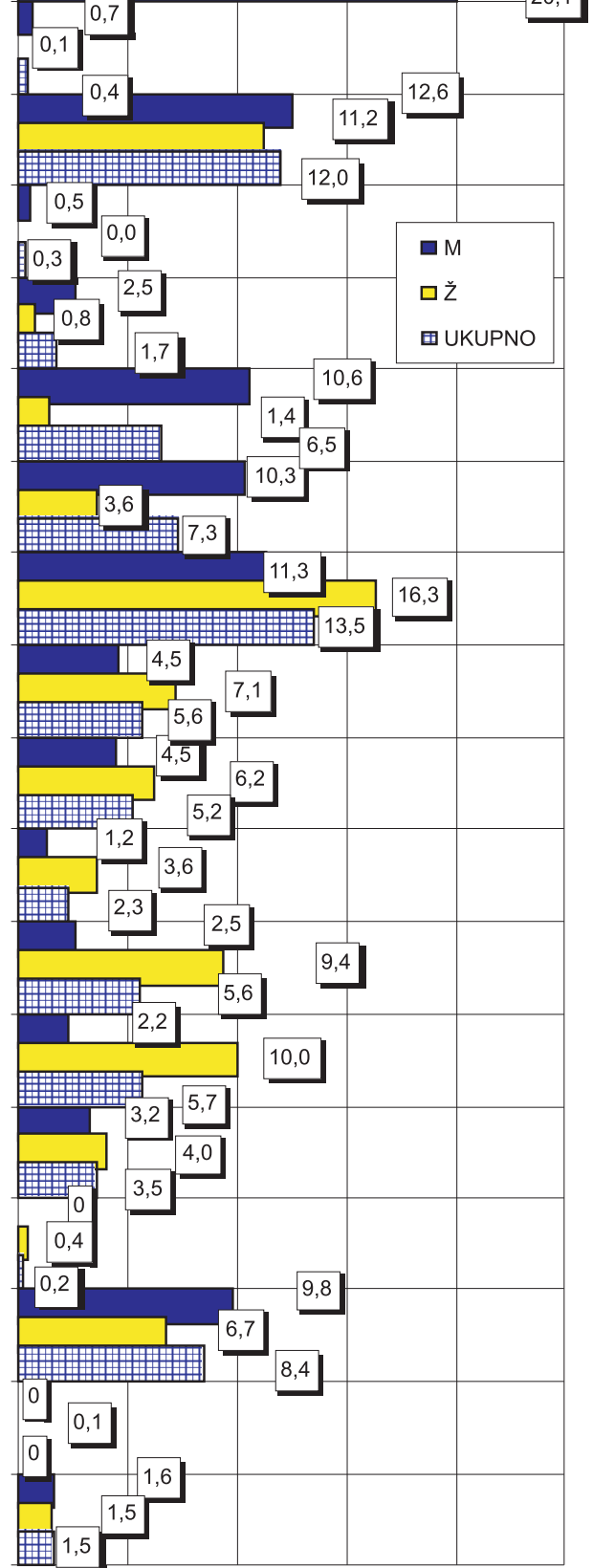
(1) SLIKA 5

Promiene u strukturi

radno aktivnoga

stanovništva po

sektorima dielatnosti i

spolu od 1971. do

2001. godine (\%)

$\square$ NEPOZNATO

$\square$ TERCIJARNI

$\square$ SEKUNDARNI

$\square$ PRIMARN

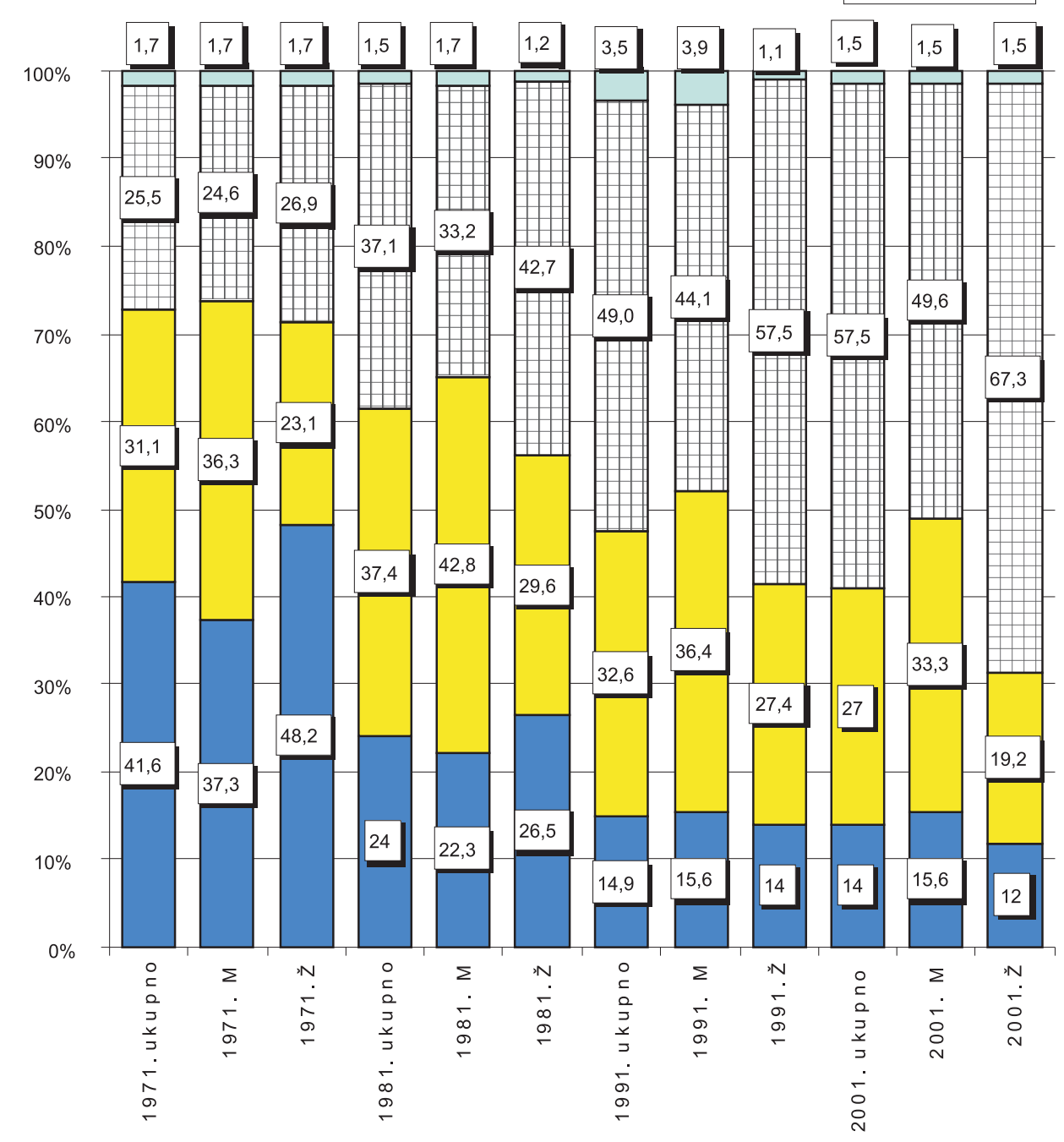

\section{Rasprava}

Analiza promjena $\mathrm{u}$ strukturi prema sektorima djelatnosti za ukupno radno aktivno stanovništvo u čitavom razdoblju od 1971. do 2001. pokazuje ponajprije zamjetan pad udjela primarnoga sektora sa 41,6 \% u 1971. na 14\% u 2001. Najveća promjena dogodila se između 1971. i 1981., kada je udio pao na $24 \%$. i nastavio padati na $14,9 \%$ u 1991 ., a najmanja se promje- 
DRUŠ. ISTRAŽ. ZAGREB GOD. 20 (2011), BR. 1 (111),

STR. 89-110

PERAČKOVIĆ, K. HRVATSKA U... na dakle dogodila između 1991. i 2001. sa 14,9\% na $14 \%$. Kod žena je udio u primarnom sektoru 1971. bio 48,2\% i najveći pad događa se do 1981. na 26,5\%. Godine 1991. taj se udio i dalje smanjuje na $14 \%$, a 2001. je udio primarnoga sektora u strukturi ženskoga aktivnog stanovništva 12\%. Muškaraca je 1971. u primarnom sektoru bilo $37,3 \%$, što je čak $11 \%$ manje od žena, a osjetniji pad dogodio se do 1981., kada je iznosio 22,3\%. Zatim se udio 1991. smanjuje na $15,6 \%$ i ostaje identičan u 2001., što znači da je proces deagrarizacije u zadnjem desetljeću usporen i stabiliziran.

U svojoj analizi Wertheimer-Baletić je konstatirala kako se najvažnije obilježje procesa ekonomskog razvoja nakon Drugoga svjetskog rata kod nas očituje prije svega u velikom transferu radne snage, ali i ukupnoga stanovništva iz poljoprivrede u nepoljoprivredne djelatnosti (Wertheimer-Baletić, 1991. 5). No ono što je autorica istaknula, a što se danas olako previđa, jest činjenica da se ta promjena nije odvijala samo prema ekonomskim zakonitostima, nego u prvom redu prema političkim načelima inicijalnoga razvoja socijalističkoga društva, koje je zahtijevalo vlastite oblike društvene organizacije rada, tj. povećanje broja i udjela radnika u društvenom sektoru privrede, a potiskivalo one koje tom društvu nisu svojstveni: individualni, sitni robni proizvođači, kategorije privatnih poslodavaca i sl.

Sekundarni sektor već je 1971. obuhvaćao 31,1\% aktivnoga stanovništva Hrvatske, 1981. raste na $37,4 \%$, a 1991. smanjuje se na $32,6 \%$, dok u tranzicijskom razdoblju do 2001. pada na $27 \%$. Žena je 1971. u sekundarnom sektoru bilo $23,1 \%$, a 1981. godine $29,6 \%$. Godine 1991. njihov se udio smanjuje na $27,4 \%$ no do 2001 . osjetno pada na $19,2 \%$. Kod muškaraca je već 1971. sekundarni sektor činio čak 36,3\% udjela, a 1981. taj udio raste na $42,8 \%$. Ipak, 1980-ih taj udio opada na 36,4\% u 1991. i nastavlja se smanjivati i u 2001. na 33,3\%. Ono što je ovdje očito jest da je smanjenje sekundarnoga sektora započelo već između 1981. i 1991., i to za 4,8\%. Trend smanjivanja nastavlja se i u 1990-ima i do 2001. smanjuje se za još 5,6\%. No ono što iznenađuje jest da se udio radno aktivnih muškaraca u sekundarnom sektoru više smanjio između 1981. i 1991. - za 6,4\% - nego između 1991. i 2001., kada je smanjen za 3,1\%. Nasuprot tome, kod žena se, od 1981. do 1991., udio smanjio za 2,2\%, no do 2001. osjetnije se smanjuje, čak za 8,2\%. Dakle, ono što se prvo može uočiti iz ovih podataka jest da je proces industrijalizacije dosegnuo svoj vrhunac do početka 1980-ih godina te da otada zapravo započinje deindustrijalizacija koja traje do danas, jedino se javljaju i drugi (novi) čimbenici koji je ubrzavaju 1990-ih godina: agresija na Hrvatsku, privatizacija društvenoga sektora proizvodnje, informatizacija, globalizacija tržišta te zamah procesa tercijarizacije zbog veće potraž- 
DRUŠ. ISTRAŽ. ZAGREB GOD. 20 (2011), BR. $1(111)$ STR. $89-110$

PERAČKOVIĆ, K.: HRVATSKA U...

\section{ZAKLJUČAK}

nje za postojećim uslužnim djelatnostima i nastajanja novih usluga.

Tercijarni sektor $\mathrm{u}$ analiziranom razdoblju ima najveću ekspanziju: od 25,5\% aktivnih u 1971. na 57,5\% u 2001., dakle udio se udvostručuje u zadnjih 40 godina. Kao što se vidi na slici 5, taj je rast kontinuiran i podjednak u svakom međupopisnom razdoblju i zapravo je stepenast: 1981. raste na $37,1 \%$, a 1991. na $49 \%$ i do 57,5\% u 2001. Prema tome, trenutačno više od polovice radno aktivnoga stanovništva pripada tercijarom sektoru. Kod žena je porast još izraženiji: 1971. bilo ih je 26,9\%, a 1981. raste na čak $42,7 \%$, tako da je najviše radno aktivnih žena bilo u tercijarnom sektoru. Trend rasta nastavlja se u 1991. na $57,5 \%$ te još intenzivnije raste do 2001 . na čak $67,3 \%$, što znači da je $2 / 3$ radno aktivnih žena danas u tercijarnom sektoru, što je porast za 40,4\% u 40 godina. Kod muškaraca također postoji kontinuirani rast udjela: 1971 . ih je bilo $24,6 \%$, a 1981. ih je u tercijarnom sektoru bilo radno aktivnih $33,2 \%$. Do 1991. udio je zamjetnije narastao na $44,1 \%$ nego do 2001., kada ih je bilo 49,6\%, odnosno polovica radno aktivnih. Ukupan porast za muškarce je od 1971. do 2001. bio $25 \%$, što je ipak znatno manje nego kod žena. Dakle, kao što je smanjivanje sekundarnoga sektora započelo od 1980-ih godina, tada je započeo i rast tercijarnoga sektora. Drugim riječima, tercijarizacija i deindustrijalizacija dva su istodobna i povezana procesa, koji ujedno označuju i odljev radne snage iz sekundarnoga sektora u tercijarni, kao što su u prošlosti bili povezani deagrarizacija i industrijalizacija. Međutim, taj proces uočava Wertheimer-Baletić veći između 1953. (koja je također bila popisna godina) i 1971. i konstatira da je bio brži porast udjela radno aktivnih osoba u tercijarnim djelatnostima nego u sekundarnima (Wertheimer-Baletić, 1991., 47), što je važna spoznaja za zaključno razmatranje. Prema tome, i u ovom slučaju može se reći da je proces tercijarizacije stalan, samo su u nekim razdobljima na njega utjecali razni čimbenici, uglavnom isti oni koji su dovodili i do deindustrijalizacije.

Svrha ovoga rada nije bila donijeti neki generalni zaključak o tome da je Hrvatska ušla u postindustrijsko doba, nego ponajprije prikazati analizu jednog od fundamentalnih pokazatelja toga procesa, a to je promjena u strukturi djelatnosti. Iz navedenih statističkih pokazatelja očito je da, osim deagrarizacije kao procesa smanjenja poljoprivrednih zanimanja i djelatnosti, već od 1981. započinje i postupan proces deindustrijalizacije, tj. smanjenja udjela industrijskih zanimanja i djelatnosti, no ono što je još očitije: započinje i proces tercijarizacije - rast udjela uslužnih zanimanja i djelatnosti, ali još od 1971., pa je od tada do 1981. bio i najveći skok od 12\%, čak 
DRUŠ. ISTRAŽ. ZAGREB GOD. 20 (2011), BR. $1(111)$

STR. 89-110

PERAČKOVIĆ, K. HRVATSKA U... veći nego u tranzicijskom razdoblju u kojem ukupne promjene i nisu bile najizraženije kako se očekivalo. Stoga se početna hipoteza da je i u Hrvatskoj započela postindustrijska promjena strukture djelatnosti može prihvatiti, iako se ne može egzaktno empirijski izmjeriti koji čimbenici i u kojoj mjeri utječu na tu transformaciju. Sigurno postoji dugoročan sinergijski učinak procesa demografske tranzicije, tehničke modernizacije (Rogić, 2000.) i produljenja općeg obrazovanja uz ulazak žena u radni kontingent. Ovamo svakako treba pribrojiti i razvoj globalne i informacijske ekonomije (Castells, 2000.), proces marketizacije društva (Peračković, 2008.) i razvoj kulture konzumerizma (Čolić, 2008.), kao i posljedice rata i tranzicije (Županov, 1995.; Rogić i Čengić, 1999.). Sve veći udio starijega stanovništva zahtijevao je sve veći broj uslužnih djelatnosti na području zdravstvene i socijalne skrbi, a obvezno osnovnoškolsko obrazovanje i veći rast udjela srednjeg obrazovanja dovodi do veće potražnje za prosvjetnim zanimanjima i do masovnijeg ulaska žena na tržište rada, što također zahtijeva sve veću potražnju zanimanja koja su prije bila zadaća žena u kućanstvu. Tehnička modernizacija, najprije kao automatizacija, pa potom i informatizacija industrijske proizvodnje, smanjila je udio industrijskih zanimanja i djelatnosti te dovela do tzv. tehnoloških viškova još u 1980-im godinama, a postupna marketizacija društva i otvaranje prema tržišnom modelu sve je više međuljudskih interakcija pretovarila $u$ tržišne odnose. Globalna ekonomija i preseljenje industrijske proizvodnje uz preseljenje tvornica iz najrazvijenijih zemalja u zemlje jeftine radne snage i Kinu zacijelo je pridonijelo i sve većoj deindustrijalizaciji, što nije zaobišlo ni nas, pa je i u Hrvatskoj stranim investitorima neisplativo ulagati u preskupu proizvodnju. Tu su još i demografske i ekonomske posljedice Domovinskoga rata te potom posljedice privatizacije, koje su dodatno razorile razvojne mogućnosti prestrukturiranja privrede i produbile deindustrijalizaciju, a nagli rast potrošačkoga društva, uz tradicionalnu sklonost pretjeranoj potrošnji građana Hrvatske, pridonio je sve većoj tercijarizaciji, osobito masovnim otvaranjem trgovačkih centara u proteklom desetljeću.

Ovo su samo najvažniji čimbenici postindustrijske preobrazbe na hrvatski način. Međutim, u našem slučaju postindustrijalizacija nema isti učinak kao u najrazvijenijim zemljama i oznaka postindustrijskog nije pokazatelj društvenoga i ekonomskoga razvoja, jer uz ovakvu dobnu i obrazovnu strukturu stanovništva uslužni sektor nije dobio funkciju privrednoga razvoja nego puke reprodukcije ovisne o državnom proračunu. Takva struktura stanovništva, uz navedene čimbenike deindustrijalizacije, pogoduje da Hrvatska postane tek puki servis na periferiji (Peračković, 2006.): društvo konobara, pro- 
DRUŠ. ISTRAŽ. ZAGREB GOD. 20 (2011), BR. $1(111)$ STR. $89-110$

PERAČKOVIĆ, K. HRVATSKA U.. davačica, skladišnih i transportnih radnika, sezonskih pomoćnih radnika u turizmu i sl. Na kraju može se zaključiti da $\mathrm{Hr}-$ vatska u postindustrijsko doba nije postala razvijenije postindustrijsko društvo u smjeru razvoja zemalja koje je Castells analizirao, već prije društvo jeftinih (u)sluga. $\mathrm{S}$ takvom današnjom slikom, uz nepostojanje dugoročnih društvenih i ekonomskih strategija prestrukturiranja i razvoja, ideja da će $\mathrm{Hr}$ vatska postati društvo znanja ulaskom u EU ostaje, nažalost, samo utopija.

\section{BILJEŠKE}

${ }_{1}$ Autor pojma postindustrijsko društvo jest američki sociolog Daniel Bell, koji u knjizi Dolazak postindustrijskoga društva dijeli društvo na tri područja: tehnoekonomsko, političko i kulturno. Uvid u samo neke od najvažnijih fakultetskih udžbenika sociologije pokazuje da postoji općeprihvaćena podjela na predindustrijska, industrijska i postindustrijska društva, odnosno predmoderna, moderna i postmoderna društva. U prvoj podjeli glavni je kriterij za stvaranja te tipologije stupanj tehničke modernizacije uz pripadajuću strukturu privrednih djelatnosti i zanimanja unutar privredne, odnosno, prema Bellu, tehnoekonomske sfere društva, a u drugom je to proces promjene društvenih vrijednosti kao obilježje u sociokulturnoj sferi društva. Stoga postindustrijsko nije sinonim za postmoderno, što je važno istaknuti.

2 Ta je struktura djelatnosti prema demografskim izvorima jedan od elemenata ekonomsko-socijalne strukture, koja se sastoji, osim strukture djelatnosti, i od strukture zanimanja, položaja u zanimanju i radnoj aktivnosti. To su pokazatelji koje demografi zasebno analiziraju, a zajedno ih prikazuju uglavnom u knjigama ili većim studijama, što i nije moguće $u$ jednom znanstvenom članku.

3 U svom članku "Porast značenja usluga u svjetskom gospodarstvu" R. Jovančević (1997.) ističe kako su se usluge do 1935. nazivale tercijarnim djelatnostima, sve dok A. G. B. Fisher u svojoj knjizi "The Clash of Progress and Security" nije predložio termin "uslužne djelatnosti", što je prihvatio i Colin Clark te svi kasniji ekonomisti. Stoga, u nedostatku primjerenijega termina, može se predložiti pojam tercijarizacija, definiran kao proces koji označuje prevladavanje uslužnih djelatnosti i zanimanja u strukturi privrednih djelatnosti i zanimanja nekoga društva, kao i porast udjela uslužnih djelatnosti u bruto domaćem proizvodu.

4 Bell je prvi put upotrijebio izraz postindustrijsko društvo 1959. na jednom pozvanom predavanju u Salzburgu.

${ }^{5}$ Bellova knjiga nije prevedena, a u domaćim znanstvenim radovima na području društvenih znanosti gotovo uopće nije citirana.

6 Pojam djelatnost označuje privrednu djelatnost, a prema metodologiji popisa 1991., definirana je kao "vrsta proizvodnje ili usluga kojom se bavi radnik ili druga organizacija u kojoj osoba obavlja zanimanje" (Wertheimer-Baletić, 1999., 497).

7 Važno je napomenuti da $u$ analizu nisu ušli podaci o građanima na privremenom radu u inozemstvu. 
Akrap, A. (1996.), Determinante regionalnih promjena ekonomski aktionog stanovništva Republike Hrvatske, Doktorska disertacija, Zagreb, Ekonomski fakultet.

Baletić, Z. (1998.), Zaposlenost u postindustrijskom društvu. Ekonomski pregled, 49 (9/10): 886-898.

Bell, D. (1999.), The Coming of Postindustrial Society: A Venture in Social Forecasting, New York: Basic Books.

Castells, M. (2000.), Uspon umreženog društva, Zagreb: Golden Marketing.

Clark, C. (1957.), The Conditions of Economic Progress, London: Macmilan.

Čolić, S. (2008.), Sociokulturni aspekti potrošnje, potrošačke kulture i društva. Društvena istraživanja, 17 (6): 953-974.

Fisher, I. (1939.), Production, Primary, Secondary and Tertiary. Economic Record, 15 (June): 24-38.

Hirschhorn, L. (1988.), The Post-Industrial Economy: Labour, Skills, and the New Mode of Production. The Service Industries Journal, 8 (1): 19-38.

Jovančević, R. (1997.), Porast značenja usluga u svjetskom gospodarstvu. Tourism and Hospitality Management, 3 (1): 53-56.

Matković, T. (2003.), Restrukturiranje rada? Transformacija strukture zaposlenosti. Revija za socijalnu politiku, 10 (2): 161-184.

Peračković, K. (2006.), Društvo usluga - Promjene u socio-profesionalnoj strukturi radno aktionog stanovništva Hrvatske od 1971. do 2001., Doktorska disertacija, Filozofski fakultet Sveučilišta u Zagrebu.

Peračković, K. (2007.), Promjene u strukturi zanimanja od 1971. do 2001. - Od ratara do konobara. Sociologija i prostor, 3/4: 377-396.

Peračković, K. (2008.), Društvo i (ili) tržište - sociološka konceptualizacija procesa marketizacije društva. Društvena istraživanja, 17 (6): 975-998.

Popis stanovništva i stanova 1971., Rezultati po republikama i pokrajinama, Beograd, Savezni zavod za statistiku, 1971., str. 24.

Popis stanovništva 1991., Državni zavod za statistiku, Zagreb, Dokumentacija 885.

Popis stanovništva Hrvatske 2001., Zagreb, Državni zavod za statistiku, elektroničko izdanje, http://www.dzs.hr/Hrv/Popis, Tablica 9: "Zaposlene osobe stare 15 i više godina prema starosti, spolu, djelatnosti i najvišoj završenoj školi".

Rogić, I. (2000.), Tehnika i samostalnost, Zagreb: Hrvatska sveučilišna naklada.

Rogić, I. i Čengić, D. (1999.), Privatizacija i javnost, Zagreb: Institut društvenih znanosti Ivo Pilar.

Rostow, W. W. (1997.), The Stages of Economic Growth: A Non-Communist Manifesto, Cambridge: University Press.

Statistički godišnjak SR Hrvatske 1984., Tablica 20. Aktivno stanovništvo Hrvatske koje obavlja zanimanje u zemlji prema djelatnostima 1981. 
DRUŠ. ISTRAŽ. ZAGREB GOD. 20 (2011), BR. $1(111)$ STR. $89-110$

PERAČKOVIĆ, K. HRVATSKA U...
Touraine, A. (1980.), Postindustrijsko društvo, Zagreb: Globus.

Wertheimer-Baletić, A. (1978.), Ekonomska aktionost stanovništva - demografski aspekti, Zagreb: Školska knjiga.

Wertheimer-Baletić, A. (1991.), Promjene u ekonomsko-socijalnoj strukturi stanovništva Hrvatske u poslijeratnom razdoblju, Zagreb: Ekonomski fakultet i Institut za ekonomska istraživanja.

Wertheimer-Baletić, A. (1999.), Stanovništvo i razvoj, Zagreb: Nakladnik MATE.

Županov, J. (1995.), Poslije potopa, Zagreb: Nakladni zavod Globus.

\section{Croatia in the Postindustrial Age - Changes in the Structure of Economic Activities of Working Population by Gender}

Krešimir PERAČKOVIĆ

Institute of Social Sciences Ivo Pilar, Zagreb

In Croatian society in the past half century there has been a radical change in the structure of economic activities. After the Second World War, the phase of deagrarization began, then the phase of socialist industrialization, which had its peak in the late 1960s and early 1970s. Since the 1970s, a massive entry of women into the labor market started, as well as the processes of tertiarization and deindustrialization, which became in the 90s the most dominant processes in changing industries. Besides the analysis of changes, the aim of this study was also to point out the relevance and timeliness of some of today's already classical theoretical concepts presented in the work of economic theorists Fisher, Clark and Rostow, on whose foundations occurs the modern concept of postindustrial society in the works of sociologists Bell, Touraine and Castells. Starting from the basic thesis of these authors as a theoretical framework, the author presents in this paper an analysis of changes in the structure of the active labor force by sector of activity and gender, based on the results of a census from 1971 to 2001 . Finally, discussed in the paper are the possible factors influencing these changes as well as some of the consequences to which this process leads.

Keywords: postindustrial society, service society, deindustrialization, tertiarization, structure of economic activities 
DRUŠ. ISTRAŽ. ZAGREB GOD. 20 (2011) BR. 1 (111),

STR. $89-110$

PERAČKOVIĆ, K. HRVATSKA U...

\section{Kroatien im postindustriellen Zeitalter - Veränderungen in der Struktur der berufstätigen Bevölkerung nach Tätigkeitsbereichen und Geschlechtszugehörigkeit}

Krešimir PERAČKOVIĆ

Ivo Pilar-Institut für Gesellschaftswissenschaften, Zagreb

Die kroatische Gesellschaft hat in den letzten 50 Jahren radikale Veränderungen in der Struktur der verschiedenen Tätigkeitsbereiche durchgemacht. Nach dem Zweiten Weltkrieg setzte eine Phase der Deagrarisierung und der sozialistischen Industrialisierung ein, die Ende der 60er und Anfang der 70er ihren Höhepunkt erlebte. Bereits in den 70er-Jahren setzt ein massiver Andrang von Fraven am Arbeitsmarkt ein, gefolgt von Prozessen der Tertiarisierung wie auch der Deindustrialisierung, die in den 90ern zu den dominanten Entwicklungen im Strukturwandel der Tätigkeitsbereiche werden. Der Verfasser möchte diese Veränderungen nicht nur analysieren, sondern auch die Relevanz und Aktualität bestimmter theoretischer Konzepte hervorheben, die heute bereits zu den Klassikern zählen: Dazu gehören die Arbeiten der Wirtschaftstheoretiker Fisher, Clark und Rostow, deren Ausführungen eingebaut sind in die Grundlagen des zeitgenössischen Konzepts der postindustriellen Gesellschaft der Soziologen Bell, Touraine und Castells. Ausgehend von den Grundthesen der genannten Autoren als dem theoretischen Rahmen, bringt der Verfasser eine Analyse des Wandels in der Struktur der berufstätigken Bevölkerung, betrachtet je nach

Tätigkeitsbereich und Geschlechtszugehörigkeit; er stützł sich dabei auf die Ergebnisse sämtlicher Volkszählungen von 1971 bis 2001. Abschließend wird untersucht, welche möglichen Faktoren diese Wandel und bestimmte Konsequenzen beeinflusst haben könnten.

Schlüsselbegriffe: Postindustrielle Gesellschaft, Dienstleistungsgesellschaft, Deindustrialisierung, Tertiarisierung, Tätigkeitsbereiche 